\title{
IQTISHODUNA
}

IQTISHODUNA: Jurnal Ekonomi Islam

E-ISSN: 2443-0056, P-ISSN: 2252-5661

Accredited Sinta 2 Number 148/M/KPT/2020

Volume 10 Issue 1, April 2021 | Page: 077-088

DOI: $\underline{\text { doi.org/10.36835/iqtishoduna.v10i1.928 }}$

\section{Development of Strategy and Sustainability of Bank Syariah Mandiri Management in The Face of Covid-19 Pandemic}

\author{
Renny Oktafia ${ }^{*}$, Diah Krisnaningsih ${ }^{2}$, Tika Widiastuti ${ }^{3}$ \\ 1,2Departement of Sharia Banking, Faculty of Islamic Religion, Universitas Muhammadiyah \\ Sidoarjo, Jl. Mojopahit 666-B Sidoarjo 61215, Indonesia \\ ${ }^{3}$ Departement of Sharia Economic, Faculty of Economic and Business, Universitas Airlangga, J1. \\ Jl. Airlangga No.4 - 6 Surabaya 60115, Indonesia
}

\begin{abstract}
Bank Syariah Mandiri is a sharia-based financial industry that serves as advancing economic growth in Indonesia. The Covid-19 pandemic has greatly affected the community, including the sharia banking industry sector. The purpose of this research is to answer the problem formulation regarding the implementation of Bank Syariah Mandiri management strategies to survive the COVID-19 pandemic by undertaking several risk mitigation measures, namely (1) restructuring customers applying for financing; (2) perform backups; (3) creating a customer base; (4) create a webinar program as a gathering and outreach to customers; (5) teller and customer service employees are required to be able to market and have their customers. The number of assets, financing, deposits and profits of Bank Syariah Mandiri during the pandemic experienced the best increase during its establishment. The condition of the development of Bank Syariah Mandiri is good because since 2015 it has begun to improve the work system to modern technology. Also, Bank Syariah Mandiri is developing well and has collaborated with several agencies such as BUMN, civil servants, hospitals, private employees, the Ministry of Religion, and the Ministry of Finance.
\end{abstract}

Keywords: bank syariah mandiri, covid-19, sharia bank strategy.

Article History:

Received: January 9, 2021; Accepted: February 27, 2021; Published:

April 1, 2021

*Corresponding author: e-mail renny.oktafia@umsida.ac.id

Paper type: Research paper

Cite this document: Oktafia, Renny, Krisnaningsih, Diah, AND Widiastuti, Tika. " Implementation of Bank Syariah Mandiri Management Strategies to Survive the Covid-19 Pandemic" IQTISHODUNA: Jurnal Ekonomi Islam [Online], Volume 10 Number 1 (April 1, 2021)

Abstrak: Bank Syariah Mandiri merupakan industri keuangan berbasis syariah yang berperan memajukan pertumbuhan ekonomi di Indonesia. Pandemi covid-19 bagi masyarakat sangat mempengaruhi termasuk sektor industri perbankan syariah. Tujuan dilakukan penelitian untuk menjawab rumusan masalah tentang penerapan strategi pengelolaan Bank Syariah Mandiri untuk bertahan ditengah pandemi covid-19 dengan melakukan beberapa mitigasi resiko, yaitu (1) menrestrukturisasi nasabah yang mengajukan pembiayaan; (2) melakukan pencadangan; (3) menciptakan customer base; (4) membuat program webinar sebagai silaturahmi dan sosialisasi ke nasabah; (5) bagi karyawan teller dan customer service diwajibkan untuk bisa marketing dan mempunyai nasabah sendiri. Bank Syariah Mandiri dimasa pandemi jumlah aset, pembiayaan, DPK dan laba mengalami peningkatan terbaik selama berdiri. Kondisi perkembangan Bank Syariah Mandiri yang begitu baik disebabkan sejak tahun 2015 sudah mulai memperbaiki sistem kerja hingga teknologi yang dibuat secara modern. Sehingga 
dimasa pandemi covid-19 Bank Syariah Mandiri sudah kuat dan sudah bekerja sama dengan beberapa instansi seperti BUMN, PNS, Rumah Sakit, Pegawai Swasta, Kementrian Agama, dan Kementrian Keuangan.

Kata kunci: Bank Syariah Mandiri,Covid-19, Strategi Bank Syariah.

\section{INTRODUCTION}

Based on law no. 21 of 2018, The Sharia Banking Industry is a financial institution that has business activities based on the principles of Islamic law regulated by the Fatwa of Majelis Ulama Indonesia (MUI), aims to carry out benefit behavior and stay away from bad behavior such as gharar, usury, maysir, cruel and all behavior that is prohibited by Allah SWT 1. The Sharia Financial Industry serves as one of the main drivers in improving the quality of Indonesian citizens to increase and accelerate economic growth in the real sector in business activities that have sharia principles ${ }^{2}$.

For the sharia financial industry to develop rapidly, the government has formed a Komite Nasional Keuangan Syariah (KNKS) issued by Peraturan Presiden (Perpres) No. 91 of 2016, Komite Nasional Keuangan Syariah (KNKS) was formed aims to make Indonesia the main vehicle for driving the Islamic economy, as well as becoming a target market and industrial products in other countries ${ }^{3}$. The sharia financial

1( Financial Fervices Authority, 2017)

${ }^{2}$ Yoga Adi Surya and Binti Nur Asiyah, "Analisis Perbandingan Kinerja Keuangan Bank BNI Syariah Dan Bank Syariah Mandiri Di," Iqtishodia: Jurnal Ekonomi \& Perbankan Syariah 7, no. 2 (2020): 171.

${ }^{3}$ Diharpi Herli Setyowati, Ayu Sartika,

and Setiawan, "Faktor-Faktor Yang industry has a social function as a Baitul Maal institution which aims to receive funds from the proceeds of zakat, infaq, alms, and other social funds and then will be distributed to those who manage waqf or commonly reffered to as nadzir ${ }^{4}$.

Sharia Bank is a financial institution whose activities are to provide financing and other services in payment traffic and money circulation based on Islamic sharia principles ${ }^{5}$. Also, Bank Sharia can provide service from various kinds of financial services such as making payments, saving, current account and time deposits, to making financing for community needs and as a place to activities in terms of currency exchange ${ }^{6}$.

The Sharia bank in the law article 1 no. 21 of 2018 explains that sharia banking is a bank that carries out its business activities based on sharia principles, and has types consisting of Bank Umum Syariah and Bank Pembiayaan Rakyat

Mempengaruhi Pangsa Pasar Industri Keuangan Syariah Non-Bank," Jurnal Iqtisaduna 5, no. 2 (2019): 169.

${ }^{4}$ Otoritas Jasa Keuangan, "Perbankan Syariah Dan Kelembagaannya."

"Heri Sudarsono, Bank Dan Lembaga Keuangan Syariah: Deskripsi Dan Ilustrasi (Yogyakarta: Eksoria, 2012).

"Sutiman, "Analisis Rasio ROE Dan ROA Dalam Menilai Tingkat Kesehatan Pada PT. Bank Mandiri (Persero) Tbk Tahun 2012-2017," Jurnal Mandiri: Ilmu Pengetahuan, Seni, Dan Teknologi 3, no. 1 (2019): 20-36.

78| Copyright (C 2021, IQTISHODUNA: Jurnal Ekonomi Islam

http://ejournal.iaisyarifuddin.ac.id/index.php/iqtishoduna 

Management in The Face of Covid-19 Pandemic

Syariah. In 2020, the sharia banking industry in Indonesia will experience growth, namely to become 14 Bank Umum Syariah(BUS).

\begin{tabular}{|c|l|c|}
\hline No & \multicolumn{1}{|c|}{ Nama Bank Umum Syariah (BUS) } & Jumlah \\
\hline 1 & PT. Bank Aceh Syariah & 26 \\
\hline 2 & PT. BPD Nusa Tenggara Barat Syariah & 14 \\
\hline 3 & PT. Bank Muamalat Indonesia & 82 \\
\hline 4 & PT. Bank Victoria Syariah & 7 \\
\hline 5 & PT.Bank BRI Syariah & 67 \\
\hline 6 & PT. Bank Jabar Banten Syariah & 9 \\
\hline 7 & PT.Bank BNI Syariah & 68 \\
\hline 8 & PT.Bank Syariah Mandiri & 127 \\
\hline 9 & PT.Bank Mega Syariah & 27 \\
\hline 10 & PT.Bank Panin Dubai Syariah & 12 \\
\hline 11 & PT.Bank Syariah Bukopin & 12 \\
\hline 12 & PT. BCA Syariah & 15 \\
\hline 13 & $\begin{array}{l}\text { PT. Bank Tabungan Pensiunan Nasional } \\
\text { Syariah }\end{array}$ & 24 \\
\hline 14 & PT.Maybank Syariah Indonesia & 1 \\
\hline
\end{tabular}

Table 1

Bank Umum Syariah (BUS) Branch

Office in Indonesia

Source: www.ojk.go.id, sharia banking statistics, juli 2020

The Indonesian economy is currently experiencing a drastic decline, this is due to the Covid-19 outbreak which has spread throughout the world to Indonesia so that all industrial sectors are also feeling the impact of the Covid-19 pandemic including the Sharia financial industry ${ }^{7}$. In January 2020, statistical data from Sharia banking stated that the largest number of Bank Umum Syariah office units in Indonesia are on Java Island, which is 1,922 branches. In line with the spread of the Covid-19 outbreak, most areas are on Java Island, this

${ }^{7}$ Mardhiyaturrositaningsih and Muhammad Syarqim Mahfudz, "Dampak Pandemi Covid-19 Terhadap Manajemen Industri Perbankan Syariah: Analisis Komparatif," Jurnal Ekonomi dan Manjemen 2, no. 1 (2020): 2. shows that Bank Umum Syariah office units are in the red zone with 310 branch offices in the West Java region, while 254 branch offices are in the Jakarta area and 208 branch offices located in the East Java region 8 .

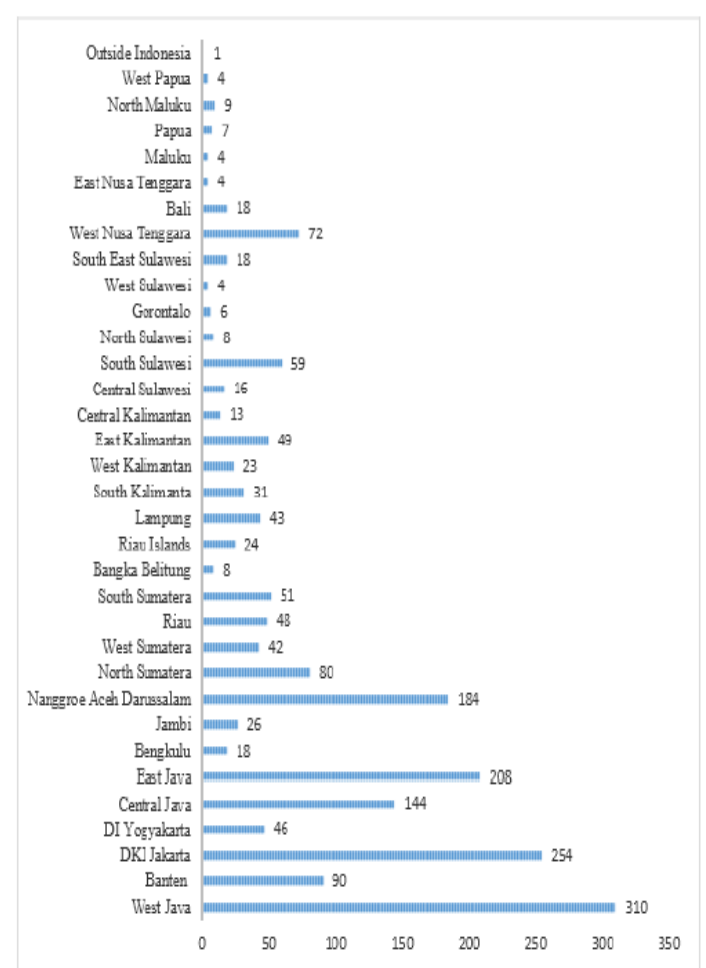

Figure 1

Bank Umum Syariah Industry Based on the Level of Distribution in Each Region Source: Sharia Banking Statistics, January 2020

The Covid-19 pandemic outbreak has had a very significant impact on society, such as laid-off and many people becoming unemployed 9 . This impact was

\footnotetext{
${ }^{8}$ (Sharia Banking Statistics, 2020)

9Yenti Sumarni, "Pandemi Covid-19: Tantangan Ekonomi Dan Bisnis," Al-
} 
tremendous to the economy resulting in the number of poverty has increased drastically ${ }^{10}$. At the time of the Covid-19 pandemic, the sharia banking industry acted as an intermediary for people who had more funds than those who needed funds to be able to do activities during the Covid-19 pandemic as well as assist the economic development strategy in Indonesia 11.

In the economic sector, Bank Syariah Mandiri serves as consumption and investment. During the Covid-19 pandemic, Bank Syariah Mandiri is needed in the economic sector, both from the distribution of financing for old customers and new customers 12 . Therefore, Bank Syariah Mandiri helps in advancing the sharia-based economy to benefit mankind, which is since the Covid-19 pandemic has had a major impact on the economy 13. The challenge of the emergence of

Intaj:Jurnal Ekonomi dan Perbankan Syariah 6, no. 2 (2020): 48.

10Yuninda Roro Yekti Nugrahana and Irham Zaki, "Peran Bank Wakaf Mikro Di Masa Pandemi Covid-19," Jurnal Ekonomi Syariah Teori dan Terapan 7, no. 9 (2020): 1732.

${ }^{11 N u r u l ~ F i t r i ~ H a b i b a h, ~ “ T a n t a n g a n ~}$ Dan Strategi Perbankan Syariah Dalam Menghadapi Covid-19," Iqtishodiah: Jurnal Ekonomi dan Perbankan Syariah 2, no. 1 (2020): 2.

12AM. M. Hafidz Ma'shum and Marlina, "Nusantara Syariah Economy (Construction of Economic Cooperation between the Indonesian Muslim Community)," IQTISHODUNA: Jurnal Ekonomi Islam 9, no. 2 (2020): 198.

13Jefik Zulfikar Hafizd, "Peran Bank Syariah Mandiri (BSM) Bagi Perekonomian the covid-19 epidemic in the management of Bank Syariah Mandiri so far needs a new change of strategy to survive during the Covid-19 pandemic because this pandemic has not yet known its expiration date, so Bank Syariah Mandiri must design a strategy and need to mitigate appropriate risks to face the Covid-19 pandemic in which economic conditions are uncertain ${ }^{14}$. In this study, researchers focused on implementing management strategies for Bank Syariah Mandiri Sidoarjo Branch Office and Sidoarjo Waru Branch Office to survive amid the Covid-19 pandemic.

\section{RESEARCH METHODS}

The type of research method used by researchers in qualitative research methods using the Grounded Theory study approach ${ }^{15}$. The reason the researchers chose to use the Grounded Theory (GT) study approach because the researchers want to reveal a phenomenon that was expected in this analysis to produce a theory that could explain the phenomenon concerning about implementation of Bank Syariah Mandiri management strategies to survive the covid-19 pandemic.

Indonesia Di Masa Pandemi Covid-19," AlMustashfa: Jurnal Penelitian Hukum Ekonomi Islam 5, no. 2 (2020): 139.

$$
{ }^{14} \text { Hani Tahliani, "Tantangan }
$$

Perbankan Syariah Dalam Menghadapi Pandemi Covid-19," jurnal Madani Syariah 3, no. 2 (2020): 98.

${ }^{15}$ Bagdan and Taylor, Prosedur Penelitian Dalam Moleong Pendekatan Kualitatif (Jakarta: Rineka Cipta, 2012).

80| Copyright (C) 2021, IQTISHODUNA: Jurnal Ekonomi Islam

http://ejournal.iaisyarifuddin.ac.id/index.php/iqtishoduna 
This research was conducted at Bank Syariah Mandiri Sidoarjo Branch Office and Sidoarjo Waru Branch Office, which is located at Komplek Ruko Sentral Jenggolo A3, Jl. Jenggolo No. 9 Pucang Sidoarjo Jawa Timur and at Komplek Ruko juanda Bussiness Centre B-01, Jl. Raya Juanda, Waru, Sidoarjo Jawa Timur.

Types and data sources in this study use primary and secondary. Primary data collection was obtained from interviews with the Head of Bank Syariah Mandiri Sidoarjo Branch Office and Sidoarjo Waru Branch Office, while secondary data was obtained from the results of the official website of Otoritas Jasa Keuangan, Law on Islamic Banking, Bank Books and Banking Strategy, Sharia Bank profile data as well as scientific work from previous research 16 .

Data collection techniques in this study used three methods, among others ${ }^{17}$ :

1. Observation using passive participation observation. This is because the researchers only see the daily activities of the person being observed without the researcher getting involved in these activities.

2. Interviews using in-depth interview techniques by giving questions to the informant.

3. Documentation is used as evidence to strengthen the result

16Moh. Nazir, Metode Penelitian, Cet.

Ke-11. (Bogor: Ghalia Indonesia, 2017).

17Sugiyono, Metode Penelitian Kualitatif, Kuantitatif, Dan RED, Cet. Ke-27. (Bandung: ALFABETA, 2018). of research carried out in the field such photos, transcript of recordings when interviews at Bank Syariah Mandiri Sidoarjo Branch Office and Sidoarjo Waru Branch Office, Website data from the Financial Services Authority, Bank Syariah Mandiri Profile Data.

The data analysis technique in this study used the stages developed by Colaizzi, including:

1. Describe the phenomenon that is being studied in the implementation of Bank Syariah Mandiri management strategies to survive of covid-19 pandemic and observe the activities carried out.

2. Collect descriptions related information from informants about the phenomenon.

3. Make a transcript following by the descriptions of all informants.

4. Write complete and in-depth description, validate the result of data analysis directly to the informants.

\section{RESEARCH RESULTS}

Asbabul Nuzul Bank Syariah Mandiri Sidoarjo Branch Office and Sidoarjo Waru Branch Office

In 2001, Bank Syariah Mandiri began planning to open branch offices in every region including in Sidoarjo Regency to expand the Bank Syariah Mandiri network in each region so it can be easily reached by people who want to use Bank Syariah Mandiri. The national branch code for Sidoarjo Branch Office is number 032, which was 
established in 2003. Meanwhile, Bank Syariah Mandiri in Waru District, Sidoarjo Regency was founded in 2011.

The consideration of establishing Bank Syariah Mandiri in Sidoarjo Regency because Sidoarjo is known as an industrial city where most of the population is Muslim. Bank Syariah Mandiri was originally established in Sidoarjo Regency and immediately became the Sidoarjo Sub-Branch Office and in its development every month it has grown, so that Bank Syariah Mandiri Sidoarjo Sub-Branch Office was appointed as the Sidoarjo Branch Office located in the main area of Surabaya. Meanwhile, for consideration in establishing Bank Syariah Mandiri in Waru Subdistrict, Sidoarjo Regency because most of the potential of the area is so wide, besides that it is due to the full capacity of customers to Bank Syariah Mandiri Branch Office in Sidoarjo to make payments for Hajj, Umrah as well as SPP college payment so that Bank Syariah Mandiri must open a Sub-Branch Office in Waru District, Sidoarjo Regency to divert some customers at Sidoarjo Branch Office to a SubBranch Office in Waru District, Sidoarjo Regency. Bank Syariah Mandiri in Waru, Sidoarjo Regency was originally established as a Sidoarjo Waru Sub-Branch Office, which is in the coordination of the Sidoarjo Branch Office. However, along with the change in the organizational structure, now Bank Syariah Mandiri Sidoarjo Waru
Branch Office is located in the main area of Surabaya, so it is now replaced with Bank Syariah Mandiri Sidoarjo Waru Branch Office. At Bank Syariah Mandiri Sidoarjo Branch Office and Sidoarjo Waru Branch Office, there is a general organizational structure.

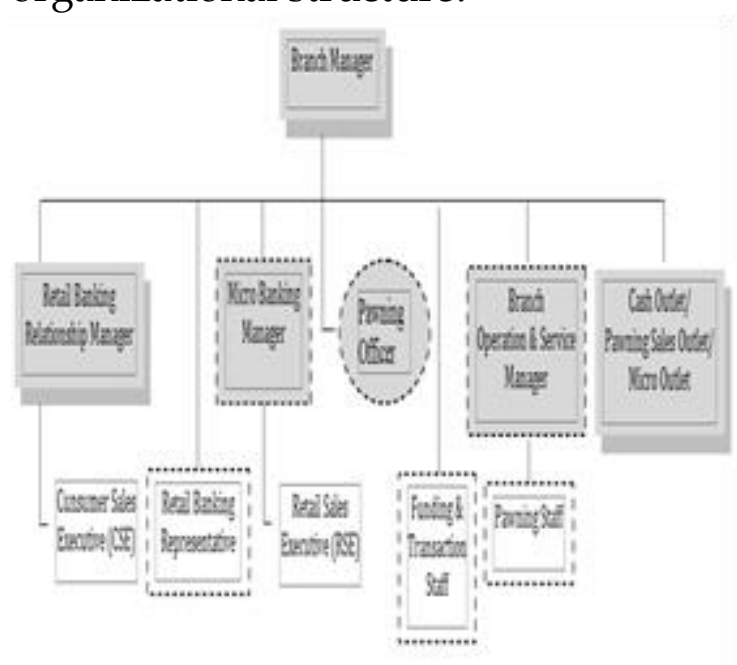

Figure 2

Organizational Structure of Bank Syariah Mandiri Sidoarjo Branch Office and Sidoarjo Waru Branch Office Source: Secondary data processed

The conditions of Bank Syariah Mandiri Sidoarjo Branch Office and Sidoarjo Waru Branch Office

The development of the Bank Syariah Mandiri Sidoarjo Branch Office during the Covid-19 pandemic was the best development condition during its establishment. Pandemic conditions caused many customers to sell shares and the proceeds from the proceeds were put into savings accounts so that the asset savings of the Bank Syariah Mandiri Sidoarjo Branch Office soared up to $13 \%$. Also, with the increasing growth of asset savings at Bank Syariah Mandiri Sidoarjo Branch Office, it

82| Copyright (C) 2021, IQTISHODUNA: Jurnal Ekonomi Islam http://ejournal.iaisyarifuddin.ac.id/index.php/iqtishoduna 
can be used for submitting customer financing requests.

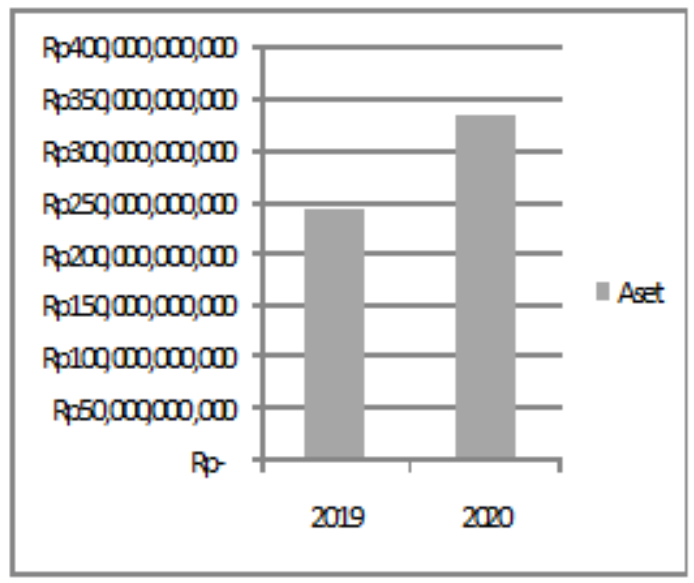

Figure 3

Assets of Bank Syariah Mandiri Sidoarjo Branch Office

Source: Secondary data processed

In the last 5 years, the assets of Bank Syariah Mandiri Sidoarjo Branch Office have increased. The results of the bar chart above show that in 2019 the total assets of Rp. $245,000,000,000$, while in 2020 during the pandemic the number of assets jumped up to Rp. 335,000,000,000. Likewise with Bank Syariah Mandiri Third-Party Funds Sidoarjo Branch Office has increased.

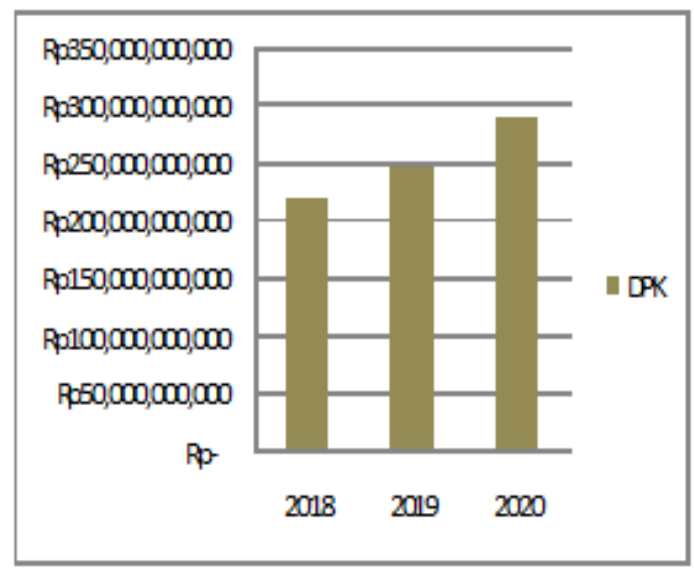

Figure 4
Bank Syariah Mandiri third-party funds, Sidoarjo Branch Office

Source: Secondary data processed

The results of the bar chart above show the Third-Party Funds of Bank Syariah Mandiri Branch Office Sidoarjo in 2018 amounting to Rp. $221,000,000,000$ in 2019, an increase of Rp. 248,000,000,000 while the year 2020 during the pandemic has increased drastically by $290,000,000,000$. When viewed from the rate of increase in each year of Rp. 40,000,000,000 to Rp. $50,000,000,000$. However, the profit of Bank Syariah Mandiri Sidoarjo Branch Office decreased by $10 \%$ because the margins had not returned and the covid-19 pandemic restructuring.

In the conditions of the Covid19 pandemic, Bank Syariah Mandiri Sidoarjo Branch Office is now more effective in disbursing financing such as hospital health bailouts which have been delayed in BPJS payments made by Sidoarjo Regional Hospital, Siti Hajar, Siti Fatimah. Bank Syariah Mandiri Sidoarjo Branch Office also provides funding almost evenly and the most are doctors, ASN, Priority (Customers who have funds above Rp. 500,000,000), while for Retail customers at Bank Syariah Mandiri Sidoarjo Branch Office, most of the funds paid are big.

The condition of the covid-19 pandemic in the development of Bank Syariah Mandiri Sidoarjo Branch Office when viewed the same as Bank Syariah Mandiri Sidoarjo Waru Branch Office, namely the best 
development conditions during the pandemic than before because sharia financial literacy is still low, customers are still few and have not collaborated with various agency. As a result of the impact of the Covid-19 pandemic affecting travel customers for Hajj and Umrah pilgrimages to stop completely and automatically their funds are taken, thus affecting the number of assets of Bank Syariah Mandiri Office Sidoarjo Waru. In this condition, many new customers open accounts to save their money at the bank, such as individual retail customers and priority customers, therefore adding new customers can support increased asset growth.

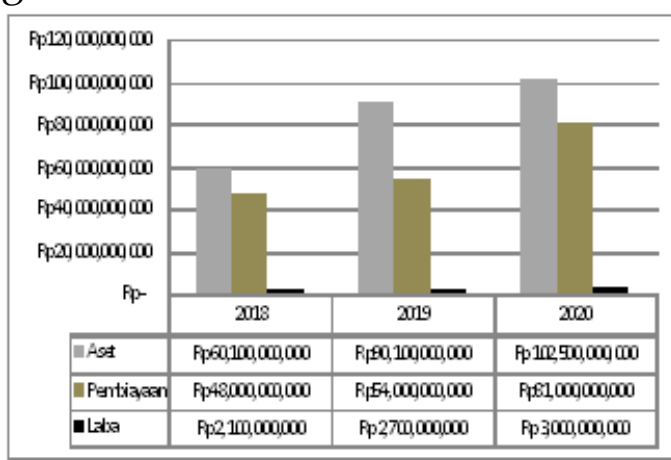

Figure 5

Assets, Financing, Profits Bank Syariah Mandiri Sidoarjo Waru Branch Office Source: Secondary data processed

In the bar chart above, it can be seen that the growth in the performance of assets, financing, and profits in each year is always increasing, while for Third-Party Funds the value is the same as assets because the assets of Bank Syariah Mandiri Sidoarjo Waru Branch Office are formed from Third-Party Funds.
Bank Syariah Mandiri Sidoarjo Branch Office in terms of financing is greater than Third-Party Funds, while Bank Syariah Mandiri Sidoarjo Waru Branch Office for Third-Party Funds is greater than financing. However, the amount of profit given is small because the income obtained by Bank Syariah Mandiri Sidoarjo Waru Branch Office is used for restructuring the Covid-19 pandemic.

Bank Syariah Mandiri during the Covid-19 pandemic was still influential, but still productive such as assets, financing, profits could still increase because during 2015 Bank Syariah Mandiri carried out organizational arrangements, so that during the pandemic they were ready.

\section{The Strategy of Bank Syariah Mandiri Sidoarjo Branch Office and Sidoarjo Waru Branch Office to Survive During the Covid-19 Pandemic}

The condition of Bank Syariah Mandiri Sidoarjo Branch Office and Bank Syariah Mandiri Sidoarjo Waru Branch Office before the Covid-19 pandemic has started preparing from the start a new strategy, namely improving work systems to technology such as improving IT, MBanking, to digitally designed products included in an online account opening system starting from 2015.

The goal of Bank Syariah Mandiri is to make improvements, namely towards modern technology, with a large transformation to start 
targeting ASN until now the digital system is now getting better and better. Even the M-Banking model of Bank Syariah Mandiri is like an ATM but cannot be used to dispense money like contents LinkAja, GoPay, OVO and Shopee balances.

The next strategy of Bank Syariah Mandiri development after improving technology is starting to implement QRIS, was at the inauguration of QRIS BCA Syariah, BNI Syariah, BRI Syariah, and BTN Syariah joined LinkAja, while Bank Syariah Mandiri had its own without joining a third party and when Bank Indonesia (BI) launched QRIS for Umrah and worship simultaneously. Bank Syariah Mandiri already has more than 200 mosques in East Java.

The strategy taken by Bank Syariah Mandiri to establish friendly relationships and socialize during the pandemic is to create a Webinar program which is held for 4-5 hours via zoom or google meet, by complying with health protocols, social distancing and Work From Home. Bank Syariah Mandiri technology that has been improved since 2015 during the pandemic has brought positive things, where transactions made at Bank Syariah Mandiri both the Sidoarjo Branch Office and Sidoarjo Waru Branch Office $50 \%$ of customers make transactions digitally while $50 \%$ are done at the teller.

Bank Syariah Mandiri Sidoarjo Branch Office in its core business for the past 3 years implementing Wholesale and Retail programs. Wholesale, which attracts customers from large companies such as BUMN, hospitals or private employees who have high grit, while Retail (medium) such as in 2014 Bank Syariah Mandiri Sidoarjo Branch Office becomes B02 which can manage state finances in routine expenditure operations, business partners and KPR , ASN, pensioners, jewelry pawning around 15-16 and above, antam and civil servant salaries can now use a payroll from Bank Syariah Mandiri but that can only be vertical, while horizontal depends on each head of the respective region.

In the Core Business of Bank Syariah Mandiri, Sidoarjo Waru Branch Office, which the directions from the Surabaya area and for now only focuses on consumptive financings such as multipurpose housing renovation mortgages, education costs, medical expenses, cars, gold, and pensioners used to channel pension funds to pensioners and used to provide pension financing. Bank Syariah Mandiri Sidoarjo Waru Branch Office has now collaborated with several agencies or ministries such as BUMN, ASN, civil servants, the ministry of religion, and the ministry of finance. ASN is meant only for vertical ministries, while for horizontal ones, they cannot enter such as service because the service follows directions from the Governor. When viewed from the percentage that has collaborated with Bank Syariah Mandiri Sidoarjo Waru Branch Office for ministries or agencies of $30 \%$ of the total employees in the tax office, AirNov Indonesia is $30 \%$ and others are still 
gradually getting to all agencies or ministries in every existing institution around Juanda.

Technology designed in a modern way by Bank Syariah Mandiri still has weaknesses, that many people do not know about the development of digital technology because of the lack of socialization from Bank Syariah Mandiri. So it is necessary to do socialization, promotion and advertisement through social media, and each employee uploads status related to digital development to make Bank Syariah Mandiri virtualize.

The strategy carried out by Bank Syariah Mandiri in mitigating risks to survive amid the Covid-19 pandemic is to make as many backups as possible even though there is or does not exist the Covid19 pandemic will still be made backups because these reserves are a policy strategy of the Bank Syariah Mandiri Head Office, however, the Financial Services Authority does not regulate the existence of these regulations and restructures customers who apply for financing by choosing carefully which customers are eligible for restructuring financing.

The next strategy was to create a Customer Base, meaning that Bank Syariah Mandiri began to increase the number of Payrolls in each agency and ministry such as ASN, BUMN, private employees, hospital employees and for every teller and customer service employee to have their respective customers and are required to be able into marketing.

\section{CONCLUDING REMARKS}

Based on the results of the discussion above carried out by researchers at the time of research related to the implementation of Bank Syariah Mandiri management strategies to survive the covid-19 pandemic, the conclusion in this study is that the current phenomenon is the covid-19 pandemic that has occurred throughout the world, including Indonesia. Bank Syariah Mandiri must be able to face challenges and strategies to survive in the covid-19 pandemic. First, Bank Syariah Mandiri risk mitigates by restructuring customers who apply for financing by choosing carefully for customers to be financed. Second, Bank Syariah Mandiri in risk mitigation complies with the Head Office policy, which is to make as many backups as possible even though the Covid-19 pandemic is present or not. Third, Bank Syariah Mandiri during the Covid-19 pandemic will focus on creating a Customer Base, namely Bank Syariah Mandiri to increase the number of employee salary payrolls in every agency, ministry, and institution such as ASN, BUMN, private employees, hospital employees. Fourth, during the pandemic, Bank Syariah Mandiri created a program by holding a 4-5 hour webinar via zoom or google meet to be able to establish friendships with customers

86| Copyright (C) 2021, IQTISHODUNA: Jurnal Ekonomi Islam

http://ejournal.iaisyarifuddin.ac.id/index.php/iqtishoduna 
or socialize. Fifth, Bank Syariah Mandiri teller and customer service employees are required to choose their respective customers and are required to understand marketing.

Bank Syariah Mandiri Sidoarjo Branch Office and Bank Syariah Mandiri Sidoarjo Waru Branch Office in the development of assets, financing, third-party funds (DPK), profits during the Covid-19 pandemic have increased drastically and this condition is the best as long as Bank Syariah Mandiri was established. Since 2015, the development of Bank Syariah Mandiri has started to improve itself from workplace systems to technology such as IT, M-Banking, and digitally designed products including opening an account that can be done online. Bank Syariah Mandiri carried out technological improvements aimed at getting to modern technology and with a large transformation to start targeting ASN. After improving technology and work systems, Bank Syariah Mandiri began implementing QRIS first compared to other sharia banks. Bank Syariah Mandiri Sidoarjo Branch Office and Sidoarjo Waru Branch Office has now collaborated with various agencies such as BUMN, hospitals, private employees, civil servants, civil servants, the Ministry of Religion, and the Ministry of Finance and Bank Syariah Mandiri also held socialization, promotion, and advertising through social media to introduce modern technological developments carried out by Bank Syariah Mandiri.

\section{REFERENCES}

Bagdan, and Taylor. 2012. Prosedur Penelitian Dalam Moleong

Pendekatan Kualitatif. Jakarta: Rineka Cipta.

Habibah, Nurul Fitri. "Tantangan Dan Strategi Perbankan Syariah Dalam Menghadapi Covid-19." Iqtishodiah: Jurnal Ekonomi dan Perbankan Syariah 2, no. 1 (2020): 2.

Hafizd, Jefik Zulfikar. "Peran Bank Syariah Mandiri (BSM) Bagi Perekonomian Indonesia Di Masa Pandemi Covid-19." AlMustashfa: Jurnal Penelitian Hukum Ekonomi Islam 5, no. 2 (2020): 139.

Ma'shum, AM. M. Hafidz, and Marlina. "Nusantara Syariah Economy (Construction of Economic Cooperation between the Indonesian Muslim Community)." IQTISHODUNA: Jurnal Ekonomi Islam 9, no. 2 (2020): 198.

Mardhiyaturrositaningsih, and Muhammad Syarqim Mahfudz. “Dampak Pandemi Covid-19 Terhadap Manajemen Industri Perbankan Syariah: Analisis Komparatif." Jurnal Ekonomi dan Manjemen 2, no. 1 (2020): 2.

Nazir, Moh. 2017. Metode Penelitian. Cet. Ke-11. Bogor: Ghalia Indonesia.

Nugrahana, Yuninda Roro Yekti, and Irham Zaki. "Peran Bank Wakaf Mikro Di Masa Pandemi Covid-19." Jurnal Ekonomi Syariah Teori dan Terapan 7, no. 9 (2020): 1732.

Otoritas Jasa Keuangan. “Perbankan 
Syariah Dan Kelembagaannya." Otoritas Jasa Keuangan 157.

Setyowati, Diharpi Herli, Ayu Sartika, and Setiawan. "FaktorFaktor Yang Mempengaruhi Pangsa Pasar Industri Keuangan Syariah Non-Bank." Jurnal Iqtisaduna 5, no. 2 (2019): 169.

Statistik, Perbankan Syariah. 2020. Industri Bank Umum Syariah Berdasarkan Tingkat Persebaran Di Setiap Wilayah.

Sudarsono, Heri. 2012. Bank Dan Lembaga Keuangan Syariah: Deskripsi Dan Ilustrasi. Yogyakarta: Eksoria.

Sugiyono. 2018. Metode Penelitian Kualitatif, Kuantitatif, Dan RED. Cet. Ke-27. Bandung: ALFABETA.

Sumarni, Yenti. "Pandemi Covid-19: Tantangan Ekonomi Dan Bisnis." Al-Intaj:Jurnal Ekonomi dan Perbankan Syariah 6, no. 2
(2020): 48.

Surya, Yoga Adi, and Binti Nur Asiyah. "Analisis Perbandingan Kinerja Keuangan Bank BNI Syariah Dan Bank Syariah Mandiri Di." Iqtishodia: Jurnal Ekonomi \& Perbankan Syariah 7, no. 2 (2020): 171.

Sutiman. "Analisis Rasio ROE Dan ROA Dalam Menilai Tingkat Kesehatan Pada PT. Bank Mandiri (Persero) Tbk Tahun 2012-2017." Jurnal Mandiri: Ilmu Pengetahuan, Seni, Dan Teknologi 3, no. 1 (2019): 20-36.

Tahliani, Hani. "Tantangan Perbankan Syariah Dalam Menghadapi Pandemi Covid19." jurnal Madani Syariah 3, no. 2 (2020): 98. 